\title{
Consumer Models in the Encounter between Supply and Demand of Electronic Administration
}

\author{
Françoise Massit-Folléa, Cécile Méadel \\ Laboratoire C2SO - Ecole Normale Supérieure - Lettres et Sciences \\ humaines, Lyon, France ; francoise.massit@club-internet.fr \\ Centre de sociologie de l'innovation, Ecole des Mines, CNRS, Paris, \\ France; cecile.meadel@ensmp.fr
}

\begin{abstract}
In the modernization process of public administration, information technologies are used as a tool to transform both its practices and its relations with its users. The new user-centric pattern comes from the market world: Customer Relationship Management becomes Citizen Relationship Management. Are the devices and tools of e-commerce convenient with the goals and practices of e-administration? Analyzing characters such as identification, deliberation, personalization and trust building reveals the limits of such a comparison and the need for a renewal of mediation functions between public and private spheres.
\end{abstract}

Keywords: customer, citizen, e-commerce, e-administration, devices, mediation

\section{Introduction}

According to the participants at a Round Table of the Telecommunications Observatory (Observatoire des Télécommunications dans la ville) in 2003: 'To meet the administered citizen's needs, Citizen Relationship Management has to be set up', along the same lines as Customer Relationship Management. 'This approach overturns the traditional logic of administration and focuses on the quality of the service as well as reception, assistance and the handling of complaints [...] It is no longer the citizen who makes an effort to reach the administration but the administration that is put at the citizen's service'. Citizen relationship management 'primarily concerns the organization of channels of information and communication around citizens' needs, especially by multiplying the channels and restructuring

Please use the following format when citing this chapter:

Massit-Folléa, F., Méadel, C., 2006, in IFIP International Federation for Information Processing, Volume 223, Social Informatics: An Information Society for All? In Remembrance of Rob Kling, eds. Berleur, J., Numinen, M. I., Impagliazzo, J., (Boston: Springer), pp. 209-217. 
information systems [...], by taking into account legislative, financial and human constraints and imperatives in terms of public service and equality in the treatment of users $[\ldots]$, in the implementation of a whole range of tools (call centers, pagers, SMS, websites, automatic message or email management, etc.)' [1]

This is not relevant only to France. According to the Austrian chairwoman of TeleCities interviewed in 2003, 'E-administration is based on the transformation of the citizen into a consumer [sic]. In North America these forms of electronic governance are part of a more general movement of transformation of the administration (New Public Management) and the challenging of its role in supporting the welfare state. Public management is evaluated above all in terms of its capacity to produce quantifiable results [2]. Everywhere, we see that public administration seems to use information technologies as a tool to transform both its practices and its relations with its users. Its ambition is to become 'user-centric'.

Under what conditions can an approach conceived of in a market perspective be adapted to the relationship between citizens and their administration? This type of approach implicitly contains some serious assumptions: the administration has to be more efficient, and 'commodifying' relations can contribute towards that; the citizen is defined in terms no longer of rights and duties but of needs; finally - and this is not the smallest difficulty - this policy of commodification of the relationship can be applied to everything affecting the information of citizens.

The subject under study in this paper is a few number of devices set up on e-administration sites. We focus on these devices rather than on the sites themselves since as we are less interested in the content - which simply consists of on-line copies of the data sheets of public services - than in the devices that form a particular type of link with the user and are designed to induce a behavior, obtain an opinion, prompt a response, and so on. These devices will be compared to the discourses of the website managers by way of several types of question.

- What assumptions are made on the citizen's competencies and expectations?

- What types of device are produced and to what extent do they draw on the logic of commercial relationships?

- What conception of the service is implemented in the concrete devices set up to create the relationship? What is the administration's position?

- What means does the e-administration have to verify the relevance of its hypotheses?

- What types of relationship are enabled by the devices?

The aim is to test a very common assumption that, whereas e-commerce invents new consumer figures (communities, education, enlightened choices, etc.), e-administration gives preference to the front office and remains in a supply logic wrapped in a new technical appearance.

At this stage of the research, almost six months before the conference, we can only clarify the issue. The goal of this preliminary paper is to improve our hypotheses. The results of our fieldwork and the validation of the hypotheses will be presented at the conference. 


\section{Why Talk of e-Administration?}

What is e-administration? First, it is an appendage of the State. Under certain conditions it shares its missions and concretizes its transformations. In the wake of WWII, the State (particularly the French State) became a supplier not only of rules and services in the general interest but also of products in the strict sense of the term (public or nationalized enterprises for the production and distribution of energy, transport, cars, etc.). Despite significant structural upheavals (for instance, the end of state monopolies), the objects concerned by e-administration still bear the marks of this trend. Use of the term therefore encompasses diverse figures and publics.

The term e-administration also covers very different spaces, which differ by their legal status, funding system, management practices, etc.: the agency with a public service mission (such as dealing with the unemployed); the local authority that produces public and political communication on town life; the legal information service; the institution with a semi-commercial mission (e.g. the postal bank), and so on.

This heterogeneity of missions relates to a wide diversity of publics. In overlapping organizational contexts (the 'administration user' being the taxpayer, the victim or culprit in a court case, the schoolchild's parent, the council housing tenant, the customer of postal services or public transport, the voter for various authorities, the Internet user testing online procedures, etc.), highly variable possibilities of 'transaction' frame the addressee's margin of maneuver. Between the citizen's duties and the user's rights there exist different levels of intervention that the eadministration ought to take into account. The first clarification therefore has to be made in relation to the type of mission that the issuer of an e-administration proposal has to fulfill, and possibly in relation to its legal form (administration of the state, public institution with different 'statuses', public service agency or subsidized representative). This enables the various communication figures in question to be distinguished.

The diversity of publics, missions and users concerned has not prevented largescale compulsory mobilization around the common notion of e-administration. Sites, applications and tools have proliferated [3]. This has also entailed many questions on the grounds for this type of transformation of communication formats and its impacts. In France, over half a dozen public reports have been commissioned since 2000 , that question the forms of citizenship at work in such applications [4] [5], and the trend is the same all over Europe [6] [7].

The unified representation of the citizen as a cell of the social body still prevails in a traditional - centralized, hierarchical, sectoral, anonymous - functioning of state services. The citizen is a 'subject' (to taxes, until recently to military service, to compulsory schooling, etc.). He or she is the motive for public action but is kept far from the definition of goals and the implementation of means. This model is useful for its integrating function that transcends social peculiarities. By contrast, the 'client approach', increasingly present in the preoccupations of public producers of goods and services, implies: a segmentation of the supply - which takes into account the client's interests, competencies, financial or other capacities -; a relative freedom of choice - which almost always leaves an alternative to the consumer but urges the 
firm to emphasize the specificity of its product or service or even to make it irreplaceable -; and finally, a form of constitution of the social link by aggregation of shared interests and no longer on an abstract uniform republican base.

Our objective is not to add an additional evaluation of the work and results of e-administration to an already long list'. It is rather to examine the proposed devices and to take literally the notion of 'citizen relationship management' in order to understand how it operates and what type of e-citizen figure is constructed. The devices of sites that will serve as a field for observation will be analyzed by comparison with the characterization that we give here of commercial spaces of interaction.

\section{Characterization of the Market-Citizen Relationship}

To ensure that supply corresponds to demand (chap. 2 [8]), e-commerce makes a number of assumptions about its customers, which it tests in many ways. The strategies are diverse: it can bargain on communities of experience, play the critical intermediary card, aim for the consumer's rationality (by comparative prices), etc. In any case, it transforms the way in which the relationship with customers is traditionally established in its field of activity. It therefore simultaneously has to redefine the service that it proposes. At this stage, four ways of analyzing the relationship with users have been selected:

- What means are made available to the user to relate to the proposed device?

- What type of interaction is organized?

- Under what conditions and with which participants?

- Is the user identified as a particular individual or a non-particularized visitor? In the former case, what forms of personalization are organized? How does the device create trust?

\subsection{Identification in Space / in the Device}

What competencies does the device assume users to have? In particular, in what space does it presume users think they are? To what extent do users participate in the construction of their demand? Do they have to correspond to a pre-established offer or is there some leeway?

In the e-commerce context, the prevailing model (at least in these early days of e-commerce) is the supermarket. Products are arranged on 'shelves' and by types of product and brand. Wandering around the supermarket is evoked by scroll-down menus, which present products by type. Each pause marks the entry into an aisle where the space is again divided up. The model is that of the rational consumer whose decisions are enlightened, but where impulsive buying is made possible by a series of commercial propositions 'slipped in' alongside the main pages (the key argument being the promotional character of the proposition).

1 Especially since the agency in charge of these issues (the ADAE) has already done a large amount of work on the subject: http//www.adae.gouv.fr/adele/ 
In the case of public sites, the competencies that users are expected to have depend on the field in which the public actor operates[9] [10]. On the site of the ANPE, the French national employment agency (Agence nationale pour l'emploi), the reference is that of job advertisements. Job offers and adverts by job seekers are presented in two different, parallel or successive but unrelated spaces. Each actor knows what he or she is looking for; there is no possible move in qualifications. This is the traditional space of supply and demand of jobs that probably supports the current organization of the labor market [11].

The user figures for whom the public sites cater are often diverse: users seeking information or wanting to communicate with an administrative service, file a complaint, understand the functioning of a benefit, and so on. To what extent can these sites provide such diverse questions? This point, even by leaving aside the digital divide, relates directly to the problem of equality in citizens' information. Considering the complexity of administrative processes, do these sites enlighten the information of all citizens or do they worsen inequalities?

Promoting e-administration usually reveals a concern for rationalization and saving money. For instance, the national portal 'service-public.fr' has been adapted as 'service-public-local.fr', designed for web sites of local authorities. With the same headings, which is good for ergonomics and routine training. However, it misses the point that the relationship between the administration and its users is not the same depending on the lifetimes, the degrees of intensity in demand or the relevance of the situation. Consequently, such initiatives have a paradoxical outcome: the main challenge is on the back-office, with the necessity of interconnecting data and services; the main effort is expected - and scarcely met - in the mediation, or intermediation, process.

\subsection{Interaction and Deliberation}

One of the noteworthy characteristics of e-commerce sites is the way in which they organize forms of interaction between suppliers and customers, and among customers themselves, by providing a range of devices. At least three levels of increasingly intense interaction can be distinguished: answering consumers' questions, making these interactions public, and organizing interactions among consumers. This takes place via a series of devices, including FAQs, forums, 'community' sites, and so on. Until now, in certain cases, this has gone as far as the creation of 'communities' of users or consumers.

E-traders are also configured as intermediaries and, in a number of services, tend to move into the background or at least not to be the only ones motivating purchases. For example, they may share assessments of goods with the web users. They thus tend to establish a collective that will, in a sense, bypass them, although with their consent. As certain promoters of e-administration projects claim, these two characteristics are transposable onto sites intended for relations with the administration.

However, contrary to e-government defenders' assertions, 'User of public services' is currently considered to be a single person (asking to be informed, to be put in contact, or to receive redress for a grievance). When he simply expresses a 
specific viewpoint or a personal belief, and most of all when he fits into public policy issues as a collective body, he or she becomes a source of problems for the civil servants, who are not prepared to deal properly with users that are reluctant or who demand change too much.

This relates to two types of question: one on the common constitution of points of view; the other on relations with decision-makers or the organization.

When a device authorizes the user to express his beliefs, his needs, his questions, or even his criticism, from what point do the participants in these discussion areas construct a collective place for debate and interaction, or even a common opinion? When, or under what conditions, do the various individual messages go beyond and embody a collective advice? On the City of Paris site, for example, the addition of opinions is an explicitly sought-after objective since the preferred - in fact the only form of interaction is consultation of Internet users by way of an opinion poll. But the feedback improvements are left to the site managers' good will, without any transparency...

What are the impacts on decision-making? Commercial sites can mobilize their consumers to transform their offer, or alter their communication tools. But in order to do so they have to allocate particular resources to the task of answering consumers' questions and monitoring their interactions or involving themselves in those interactions. The objective is very simple: go on with business. For public websites, the objectives are much more complex: to give certified information, to open an interaction delimited by legal constraints, to enforce requirements in the questionanswer process (deadline, conformity, identification, etc.). The assessment of success or failure is far less direct for e-administration, and measures are difficult to interpret. But if there is a bug, unpleasant consequences can occur in terms of control or sanction, and probably first of all on users!

\subsection{Personalizing the Demand}

Concerned about retaining their customers and increasing consumption levels, commercial sites set up devices enabling them to personalize their customer relationships: identification of consumer profile, records of former purchases, various advantages related to loyalty, and so on. Customers are identified both by their past (what they have consumed and even what interests them), by their abilities and by their behavior (e.g. e-Bay's reputation index [12]). They may, for instance, be welcomed with messages related to former sessions, or have a so-called 'personal' space.

This approach by differentiation and personalization of users is more recent in the public sector. Unlike traditional practices in the French civil service, new modes of organization have been introduced to put an end to agents' anonymity and to personalize the reception of users, trying to reconfigure the organization of services according to the citizen and no longer according to the bureaucratic territories; for example, the notion of a 'single front office' in which the citizen is considered as a whole, encompassing all his or her relations with the various public institutions. A project of website named 'my-service-public.fr' has been under testing for several years. Yet even though this personalization is a response to certain demands by 
citizens [13], it poses specific problems in the public service insofar as it has to be consistent with the basic principles of equality, neutrality and continuity.

On administrative sites, we find devices that allow forms of personalization of the service. For instance, on the ANPE site, the job seeker has to create a personal space in which to save advertisements of interest, his or her CV, etc. The same applies to employers. But this space is simply an archive accessible only to that person that has been pre-formatted to a large degree by the service. This raises questions on the specific characteristics of this form of personalization of the service and on the way in which it may be redefined.

Two patterns are competing. In the 'new public management' design, "the idea of a plural citizen related both politically and economically to the public sector is replaced with the idea of a customer being motivated only by a direct and immediate exchange with it" [14]. In the 'democratic governance' design, the solution is to be found not in efficiency but in active participation from one side, true accountability for the other side. Both actors are asked to become co-designers of the public service.

There are also other questions relating to the personalization issue. Both on commercial sites and on e-administration sites, questions are raised concerning the protection of personal data.

How is this addressed? Who guarantees that individuals are protected? What redress procedure is provided for?

\subsection{Trust and Security}

One of the crucial problems encountered by commercial sites is trust in the device. How can a remote service be provided, with people who are often new actors and sometimes anonymous (on platforms of interaction between private individuals)? A range of devices has been set up by sites to provide users or consumers with elements of assessment: identification of firms, clarification of modes of functioning, existence of a procedure for redress, etc.

Transparency is one of the means mobilized to nurture trust. For instance, e-Bay organizes a high level of transparency between sellers and buyers. The reputation of an 'e-bayer' is the sum of opinions of others on the transactions in which he or she has been involved (called the evaluation profile). His or her career is the list of goods that he or she has sold or bought, and of the 'e-bayers' with whom he or she has concluded a transaction. This transparency is nevertheless possible only with the agreement and participation of those concerned and is obtained only when they have a shared objective (e.g. organizing the security of transactions).

This transparency is also highlighted by new public management, but is it really the same thing? Probably not. The transparency in e-government faces the everlasting process of modernization of the public sector, with numerous territorial and political layers. And, on the user's side, reluctance or resistance appear to being 'captured' in interconnected files related to the control powers of the State.

Moreover, the benefits of public policies apply whether to a public service consumer, or to a public space citizen: administration managers are so devoted to e-modernization that they cannot comprehend and thus cannot solve this dichotomy. 
The challenge could be in redesigning the concept of 'public service' and in activating a more collaborative behavior in its users.

\section{To conclude}

What questions derived from Customer Relationship Management enable us to understand the change under way as the administration goes online? For as we have seen, the issue here is not just about simplifying procedures, cost-cutting or saving the time of citizens and civil servants. In a broader sense, the objective is to reconfigure the administration so that it places the citizen at the center of its preoccupations, in other words, so that its quick and good response to citizens' requests are the measure of an administration's success. The comparison with ecommerce highlights, in a particularly stark manner, the importance of useful mediation in developing such services. It is not enough for any service to just combine a device, no matter how sophisticated, and an agent, no matter how competent; the interaction between supply and demand assumes a series of tests that enable the supply (or offer) to be modified and the demand to be adjusted. In conclusion, we will note the most significant forms of this mediation.

The web user is not an isolated individual, but an actor in society, connected to numerous groups, informed and influenced by diverse viewpoints. Prescribing agents have helped him to forge his judgment - the more competent he is and hence the more capable of identifying and increasing these agents, the more numerous they become. On certain sites, this notion of prescriber is instrumentalized, as the prescribers' opinions are gathered, solicited and capitalized upon, often on a voluntary basis [15], in order to help to describe products for the greater good of the site and its customers.

Nor is the web user in front of his computer necessarily isolated in consulting the web; his learning has quite often taken place in part in a collective setting, as has his behavior in front of the device [10]. Sites take into account this common way of acting by making group behavior possible and favoring the constitution of groups of uses, but also by making visible the shared nature of certain ways of doing things.

What are the alternatives to supply?

The transaction can fail and then the question of possible recourse is raised: what enables the 'lost' web user to be reconnected to his supplier, or by the same token, what connects the service to the client? Indicating one's location and opening a space of interaction with the supplier are part of building a relationship of trust and therefore contribute to redefining the interaction between supply and demand.

To what degree can e-administration use such forms of mediation, or rather, to what extent can e-administration take place via these forms of mediation? The field research is expected to provide critical feedback on the innovations of e-administration and to analyze its link with democratic practices in the digital age. 


\section{References}

1. H. Lambling, La gestion de la relation citoyen : les TIC à l'écoute et au service des territoires. (2003).

2. J.-E. Lane, Public Sector Reform. Rationale, Trends and Problems, London: Sage, 1998.

3. D. Alcaud and A. Lakel, Les nouveaux 'visages' de l'administration sur Internet : pour une évaluation des sites publics de l'Etat. Revue française d'administration publique. 110, 2004.

4. M. Chauvière and J.-T. Godbout, Les usagers entre marché et citoyenneté, Paris: L'Harmattan, 1992.

5. B. de Quatrebarbes, Usagers ou clients : marketing et qualité dans les services publics, Paris: Ed. d'Organisation, 1996.

6. C. G. E. Young, Online Availability of Public Services: How Does Europe Progress? Brussels: European Commission DG Information Society, 2004. europa.eu.int/information_society/eeurope/2005/doc/highlights/whats_new/capgemini4.p df.

7. G. García-Arribas and F. López-Crespo, Presentation. Landscape of e-Government at the Dawn of the 21 st Century -. Upgrade. The European Journal for the Informatics Professional. IV(2), 2003. http://www.upgrade-cepis.org.

8. F. Massit-Folléa (ed.), Internet Governance: Common fact and rights., 2005. http://www.voxinternet.org/

9. Services publics : questions de communication et de management. Revue Etudes de communication. 23, 2001.

10. R. Suire, Encastrement social et usages d'Internet: le cas du commerce et de l'administration électronique. Cahier de recherche Marsouin. Mai (5), 2005. http://www.marsouin.org/article.php3?id_article $=49$.

11. E. Marchal, K. Mellet and G. Rieucau, Job Board Toolkits: Internet Matchmaking and the Transformation of Help-Wanted Ads, Noisy-le-Grand: Centre d'études de l'emploi, 2005. http://www.cee-recherche.fr/fr/c_pub3.htm.

12. C. Méadel, La qualification croisée des biens et des services ou le marché ebay. Hermès. 44, 2006.

13. Survey: Usages et attentes en matière de services publics sur l'Internet. France, Europe, Paris: Capgemini et TNS Sofres, 2005.

14. J.-P. Villeneuve, Citoyens, clients et usagers face à l'administration publique Les balises d'une relation difficile. Working paper de l'IDHEA 6, 2005.

15. M. Gensollen, Internet: Marché électronique ou réseaux commerciaux ? Revue économique. 52 (Hors série octobre 2001): p. 137-161.

http://www.brousseau.info/semnum/pdf/2003-01-06_Gensollen.pdf. 